\title{
Impact of e-service Quality on Customer Satisfaction: A Study of Afghanistan International Bank
}

\author{
Article by Ahmad Shaker Ansari ${ }^{1}$, Adil Rasool ${ }^{2}$ \\ ${ }^{1}$ Researcher, Department of Management Science, Texila American University \\ ${ }^{2}$ Asst. Professor, Department of Management Science, Bakhtar University, Kabul \\ E-mail:aansari@texilaconnect.com ${ }^{l}$
}

\begin{abstract}
Examining the effects of e-service quality dimensions on customer satisfaction in Afghanistan has been concerned. The aim of this research is to investigate the e-service quality on customer satisfaction in Afghanistan. The research is based on an empirical study using questionnaire as survey instrument to test the hypotheses. The influence of independent variables on depended variable is considered. A pre-test is conducted to obtain the preliminary assessment of internal validity of the research survey instrument, and to address objectives 300 Questionnaire is distributed among the respondents for the present study, the procedure adopted for the present study is categorized as convenience sampling method, collected data is analyzed using SPSS software. The outcome concluded that four of the proposed e-service quality dimensions have significantly positive impacts on the bank customers' satisfaction, 82 percent of customer satisfaction among customers of e-banking sector significantly depends on the proposed groups of dimensions of e-Service Quality.
\end{abstract}

Keywords: e-service, quality, customer and satisfaction.

\section{Introduction}

Through the past decades the mean of shopping goods and services through internet is growing. Businesses in the electronic commerce sector realized that website design and low prices are not the only factors for success, and must include other dimensions of e-service quality in order to achieved customer satisfaction. Customer satisfaction is a cumulative construct that is affected by service expectations and performance perceptions in any given period and is affected by past satisfaction from period to period (Nuseir et al., 2010). Reliability represents the ability of the web site to fulfill orders correctly, deliver promptly, and keep personal information secure (Parasuraman and Zeithaml, 2005; Janda et al., 2002). Customization, which is the ability of the customer to personalize the website according to his individual needs, however, this may be a challenging task, because of the lack of a human touch (Santouridis ,2009). Responsiveness, which refers to the prompt reaction of the company to customers' requests and improvement suggestions (Santouridis ,2009). The level of risk is one of the important and critical issue for customers when they do e-business specially on bank websites. Some service quality of internet banking website is important to increase customer satisfaction, these are download speed, content, design, interactivity, navigation and security (Jayawardhena and Foley, 2000). A number of academics such as Parasureamna et al. (1985, 1988); Gronroos (1990) and others have tried to identify key determinants by which a customer assesses service quality and consequently results in satisfaction or not.

\section{Problem statement}

Examining the effects of e-service quality dimensions on customers' is concerned. Discussions with recognized bank in Afghanistan revealed that they are interested to understand the dimensions of eservice quality they provide, and the extent to which customers are satisfied with the quality of eservices. This created space to conduct empirical research and study the impacts of e-service quality on customer satisfaction in Afghanistan.

\section{Research objective}

Based on the problem identified, following objective were framed for the present study as follow: 
ISSN: $2520-310 \mathrm{X}$

Obj: $\mathbf{j}_{1}$ To find out casual effect of e-service quality dimensions on customers' satisfaction.

Research Hypothesis

Based on the review of literature and the objective framed for the study, the following hypothesis was framed for testing:

$\mathbf{H}_{\mathbf{1}}$ : There is no casual effect of e-service quality dimensions on customers' satisfaction.

Theoretical framework

The details of the theoretical framework taken up for the present study is shown in Figure-1, where the relationship between e-service quality dimensions and the customer satisfaction is presented.

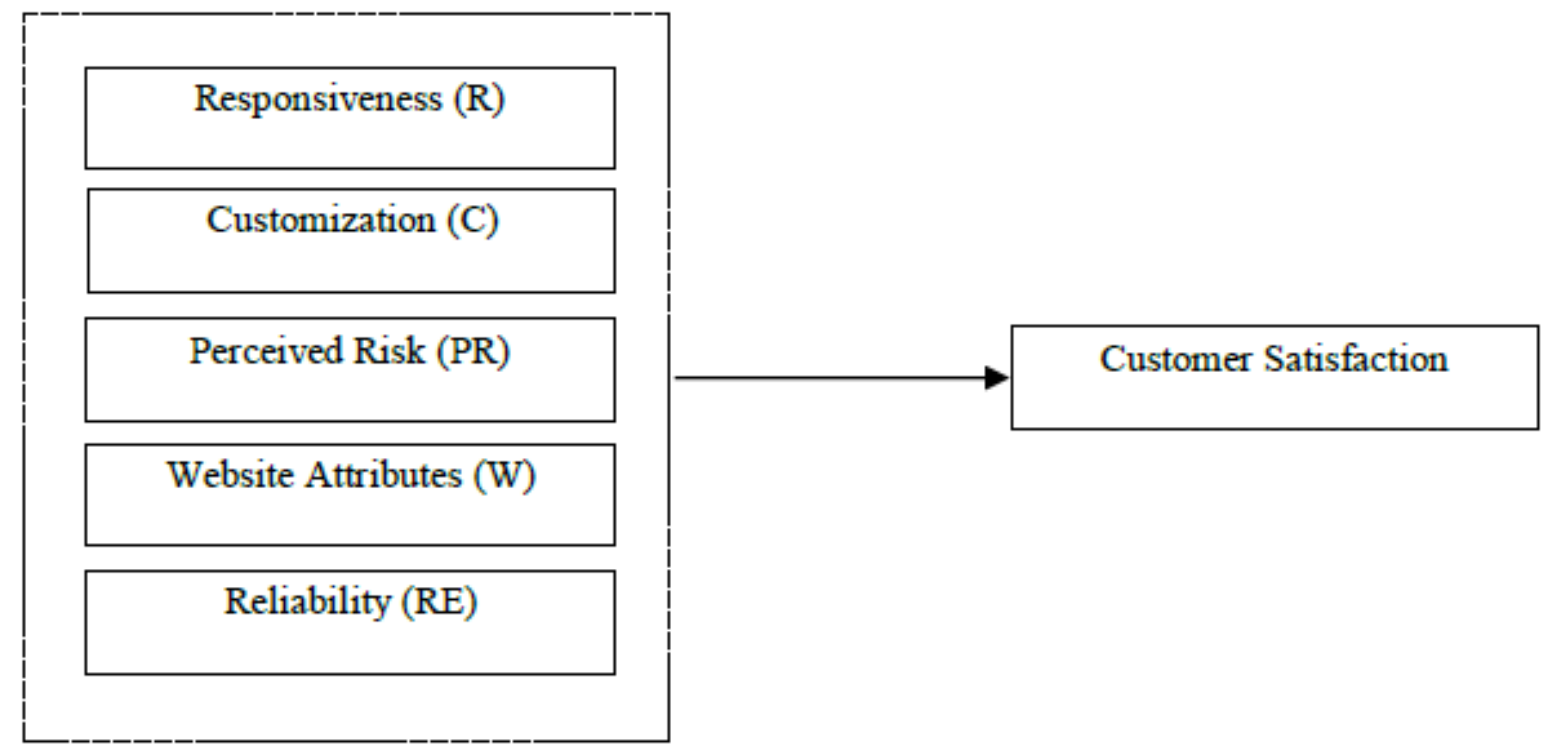

Figure-1. Diagrammatic representation of theoretical framework, (Adopted from M.T. Nuseir et al., 2010)

\section{Research methodology}

The present study will show the impact of the service quality dimensions on customer satisfaction in the services sector especially in Kabul e-banking sector. To make this study more trustworthy researcher develop a validated survey instrument in the form of questionnaire (Appendix-I) using 5-point Likert scale. Convenience sampling technique were used to collect data from 203 AIB (Afghanistan International Bank) e-banking customers. The collected primary data is processed and tested with appropriate statistical tools and techniques through latest version of Statistical Package for the Social Sciences (SPSS). Multiple regression model was applied to find out the dependency effect of service quality dimensions on satisfaction level of e-banking customers.

\section{Instrument used for primary data collection}

This work was carried out based on the primary data collected through the survey instrument. The survey instrument used for this work is a standardized well-structured questionnaire. The questionnaires were employed to collect the primary data and relevant information from the customers of banking sector. The survey instrument was designed and tested as a part of this work and proved reliable.

\section{Pre-testing}

A pilot study was conducted to obtain the preliminary assessment of internal validity of the research survey instrument questionnaire. For this purpose, primary data were collected from 20 e-banking sector customers. The results of the pilot study confirmed the internal reliability of the instrument deployed and hence, the same instrument was used in the identified sampling areas to collect the primary data needed for the present study.

\section{Survey instrument reliability}

The survey instrument was tested with appropriate reliability analysis comprising the computed value of Cronbach alpha and the alpha value for all the study variable taken up in the survey instrument is 
found to be well above the suggested value of 0.6 (Nunnally, 1978). The specific, details of alpha value for each of the study variable constituting the present work is shown in the Exhibit-1.

Exhibit-1. details of the measurement scales with corresponding reliability values

\begin{tabular}{|l|l|l|l|}
\hline S. No. & Details of the Scale & Items & Cronbach Alpha \\
\hline 1. & Website Attribute & 6 & 0.832 \\
\hline 2. & Reliability & 7 & 0.875 \\
\hline 3. & Perceived Risk & 4 & 0.972 \\
\hline 4. & Responsiveness & 5 & 0.854 \\
\hline 5 & Customization & 5 & 0.918 \\
\hline 6 & $\begin{array}{l}\text { Customer } \\
\text { Satisfaction }\end{array}$ & 6 & 0.880 \\
\hline
\end{tabular}

\section{Sampling details}

This study employed survey of e-banking customers to gather data with the help of validated survey instrument in the form of questionnaire for hypothesis testing, and to address research objectives 300 questionnaires were distributed among them. AIB (Afghanistan International Bank) e-banking customers constitute the sampling population for the present work. For the purpose of analyses of the data collected the respondents who did not respond to all questions or for whom there was a suspicion of random response such as use of the identical answer throughout is excluded. A total of 203 respondents met these inclusion criteria and thus, constitute a sample size for the present study. Since, the respondents for the survey were identified on the basis of convenience and hence, the sampling procedure adopted for the present study is categorized as convenient sampling method. The statistical tools employed for the present work comprise the basic descriptive details of the study variables. Further, Multiple Regression models were tested through SPSS as part of analysis. Based on the research models assumed and the corresponding statistical tools, hypotheses formulated in this work are tested and provided with corresponding results in the next section.

\section{Results and discussions}

From the results of table-1, it can be inferred that the F value of 23.336 is found to be significant at 5 percent level and hence, the hypothesis-1 is rejected. These results suggest that customer satisfaction depends on the group of e-Service Quality dimensions in the e-banking sector. Further, the adjusted $\mathrm{R}$ square value of 0.821 from the table- 1 indicates that 82 percent of customer satisfaction among customers of e-banking sector significantly depends on these groups of dimensions of e-Service Quality. Also, the ' $t$ ' values of 5.223, 3.114, 0.041 and 2.022 corresponding to e-Service Quality dimensions such as Service Quality Website Attribute, Service Quality Reliability, Service Quality Responsiveness and Service Quality Customization are found to be having significant effects on the model conceived.

Table 1. Result of regression for hypothesis-1

\begin{tabular}{|l|l|l|l|l|l|l|}
\hline \multirow{2}{*}{ Model } & \multicolumn{2}{|c|}{$\begin{array}{c}\text { Unstandardized } \\
\text { Coefficients }\end{array}$} & $\begin{array}{c}\text { Standardized } \\
\text { Coefficients }\end{array}$ & \multirow{2}{*}{ T } & \multirow{2}{*}{ F } & $\begin{array}{c}\text { Adjusted } \\
\text { R square }\end{array}$ \\
\cline { 2 - 5 } & B & Std. Error & Beta & & \\
\cline { 1 - 5 } (Constant) & 0.253 & 0.094 & & 1.241 & & \\
\hline Website Attribute & 0.421 & 0.131 & 0.453 & $5.223^{*}$ & & \\
\hline Reliability & 0.524 & 0.058 & 0.005 & $3.114^{*}$ & \multirow{2}{*}{$23.336^{*}$} & \multirow{2}{*}{0.821} \\
\hline Perceived Risk & 0.231 & 0.103 & 0.442 & 4.220 & & \\
\hline Responsiveness & 1.088 & 0.243 & 0.190 & $0.041^{*}$ & & \\
\hline Customization & 0.112 & 0.031 & 0.014 & $2.022^{*}$ & & \\
\hline
\end{tabular}

Source: Computed from primary data.

* Significance at $5 \%$ 
More specifically service quality website attribute among the e-banking customers is found to be having significant superior effect on customer satisfaction with highest ' $t$ ' value of 5.223. This confirms that it is easy to deal with the bank's e-services and bank's website design is easy to link and interact. It also confirms that bank's website pages have adequate, suitable colors and contains un-clear technical phrases. Similarly, Service Quality System reliability among the e-banking customers causes significantly good effect on customer satisfaction with the next higher $t$ value of 3.114. This clearly confirms the positive effects of bank sector through the features that can ensure customers and feel them sense of secure during the transaction process and can increase customers' confident and trust in quality services. Moreover, it confirms that bank is highly credible in delivering e-banking services as promised and accuracy enhances customer confidence in its services.

The ' $t$ ' value of 2.022 obtained for the service quality customization significantly causes considerable effect on the customer satisfaction in e-banking sector. This confirms the e-banking services are tailored according to customer's requirements and are changed according to changes in customer's needs and wants. It also reflects that bank's website offers special treatment for highly loyal clients and bank's eservices are changed according to changes in technology. The ' $t$ ' value of 0.041 obtained for the service quality responsiveness significantly causes considerable effect on the customer satisfaction in e-banking sector. This reveals that website responds quickly to customers' requirements and website offers the availability of an online customer services representative to respond to customer enquiries.

The remaining ' $t$ ' value of 4.220 corresponding to the dimension of service quality perceived risk is not found to be significant at 5 percent level. Hence, it can be inferred that the customer satisfaction in the e-banking sector does not depend significantly on the service quality dimension perceived risk.

\section{Limitation}

Despite the significant finding in this study, there were also several limitations. Time is considered as a main limitation of the study. The generalization of the research results is limited to the Afghanistan International Bank (AIB) and cannot be extended to the rest banks in Afghanistan. Despite having a satisfactory sample size, a larger sample size could possibly lead to more reliable results. The research model included only five dimensions of e-service quality and their effect on customer satisfaction, finding out the additional dimensions of e-service quality that affect customers' satisfaction in the future could be a good area of research.

\section{Contribution}

From the academic prospective, the study is thought to have contributed to the e-service quality and e-banking literature and fulfilled some gaps that needed more studies especially in a developing country like Afghanistan.

\section{Conclusion}

The main aim of this research was to investigate the relationship between the e-service quality dimensions and the overall customers' satisfaction in Afghanistan International Bank. Another aim was to identify the strongest determinant of the e-service quality dimensions on customers' satisfaction. Based on the research objectives, research model, analyses and outcome, number of conclusions can be outlined. Website attribute among the e-banking customers is found to be having significant superior effect on customer satisfaction. System reliability among the e-banking customers causes significantly good (with the next higher effect) on customer satisfaction. Service quality customization and responsiveness significantly causes considerable effect on the customer satisfaction in e-banking sector. Service quality perceived risk is not found to have significant effect on customer satisfaction. Finding indicates that 82 percent of customer satisfaction among customers of e-banking sector significantly depends on the above mention groups of dimensions of e-Service Quality. 


\section{Texila International Journal of Management}

Special Edition Apr 2019

\section{References}

[1]. Foley, J. a. (2000). Changes in the banking sector - the case of internet banking in UK, Internet research: Electronic Networking Applications and Policy, 10(01), 13-30.

[2]. Gronroos. (1984). A Service Quality Model and its Market Implications. European Journal of Marketing, $18(4), 36-44$.

[3]. Janda, S. T. (2002). Customer perceptions of internet retail service quality. International Journal of Service Industry Management, 13(5), 412-31.

[4]. Johnston. (1995). Identifying the Critical Determinants of Service Quality in Retail Banking: Important and Effects. International Journal of Bank Marketing, 15(4), 111-116.

[5]. Mohammed T. Nuseir, M. N. (2010). The effect of e-service quality on customers' satisfaction in banks operating in Jordan: an empirical investigation of customers' perspectives. Int. J. Services, Economics and Management, 2(1), 87.

[6]. Nunnally, J. (1978). Psychometric Methods. New York: McGraw-Hill.

[7]. Parasuraman, A. a. (2005). E-S-QUAL, A Multiple-Item. Journal of Service Research, 7, 1-21.

[8]. Santouridis, I. (2009). E-Service Quality and its Impact on Customer Satisfaction and Trust: An Empirical Study on Greek Customers of Internet Shops. 6th International Conference on Enterprise Systems, Accounting and Logistics (p. 20). Thessaloniki: Greece - PROCEEDINGS.

[9]. Zeithamal, P. a. (1988). SERVQUAL: A Multiple Item Scale for Measuring Consumers Perception. Journal of Retailing, 64(1), 64.

[10]. Zeithaml, P. a. (1985). A Conceptual Model of Quality and its Implications for Future Research. Journal of Marketing, 49, 22. 